\title{
Preservation and creation - Plainchant Notation of the Pauline Order in 14th-18th-century Hungary ${ }^{1}$
}

\author{
Gabriella GILÁNYI \\ Institute for Musicology Research Centre for the Humanities \\ of the Hungarian Academy of Sciences \\ Táncsics Mihály u. 7., H-1014 Budapest, Hungary \\ E-mail: Gilanyi.Gabriella@btk.mta.hu
}

(Received: December 2017; accepted: March 2018)

\begin{abstract}
This study surveys the musical notation appearing in the liturgical manuscripts of the Order of St. Paul the First Hermit from the fourteenth until the eighteenth century. As a Hungarian foundation, the Pauline Order adopted one of the most elaborate and proportionate Gregorian chant notations of the medieval Catholic Church, the mature calligraphic Hungarian/Esztergom style, and used it faithfully, but in a special eremitical way in its liturgical manuscripts over an exceptionally long period, far beyond the Middle Ages. The research sought to study all the Pauline liturgical codices and codex fragments in which this Esztergom-Pauline notation emerges, then record the single neume shapes and supplementary signs of each source in a database. Systematic comparison has produced many results. On the one hand, it revealed the chronological developments of the Pauline notation over about four centuries. On the other hand, it has been possible to differentiate notation variants, to separate a rounded-flexible and a later more angular, standardized Pauline writing form based on the sources, thereby grasping the transition/conversion to Gothic penmanship at the turn of the fifteenth and sixteenth centuries. A further result of the study is the discovery of some retrospective Pauline notation types connected to the Early Modern and Baroque period, after the Tridentine Council. The characteristics of the notations of the choir books in the Croatian and the Hungarian Pauline provinces have been well defined and some individual subtypes distinguished - e.g. a writing variant of the centre of the Croatian Pauline province, Lepoglava.
\end{abstract}

Keywords: Order of St. Paul the first Hermit, musical notation, tradition, musical paleography, codex fragments

1. This research was supported by the János Bolyai Research Scholarship of the Hungarian Academy of Sciences and the NKFIH research project no. K 120643. 
During the long struggle to establish the Order of St Paul the First Hermit and build up its own religious way of life in the thirteenth century, ${ }^{2}$ Paulines decided to adopt the central liturgy of Hungary - the Esztergom rite ${ }^{3}$ - and its Gregorian melodic tradition, along with a special system of musical notation. ${ }^{4}$ Nothing could show better the significance of the Pauline decision than their notating practice over the next four centuries: the firm, yet creative respect for tradition shown in a very special way even after the Tridentine reform and the dissolution of the medieval liturgical forms. ${ }^{5}$

Analyzing the Pauline musical notation marks an unparalleled opportunity for researchers into Gregorian paleography, not just for the exceptionally long period of historical development available to them for examination, but for the chronologically differentiated source materials encompassed. The surviving Pauline sources allow several different states of musical notation to be distinguished in time and space, and comparison of these stages of development allow deeply

2. Gergely Gyöngyösi, Arcok a magyar középkorból [Faces from the Hungarian Middle Ages]. Introduction and notes, Sándor Kovács, transl., Vince Árva, (Gyomaendrőd: Szépirodalmi Kiadó, 1983), 29-66; Emil Kisbán, A magyar Pálosrend története [History of the Hungarian Pauline Order] (Budapest: Pálos Kolostor Kiadása, 1940), I, 17-19; Elemér Mályusz, Egyházi társadalom a középkori Magyarországon [The Structure of Ecclesiastical Society in Medieval Hungary] (Budapest:Akadémiai Kiadó, 1971), 257-259; József Török, A magyar pálosrend liturgiájának forrásai, kialakulása és föbb sajátosságai, 1225-1600 [The Hungarian Pauline order's sources, development and main characteristics, 1225-1600] (Budapest: Római Katolikus Hittudományi Akadémia, 1977) (=Lelkipásztorkodástan és liturgika XII) [Priestly service and liturgy XII], 10-13; Zoltán Bencze and György Szekér, A budaszentlörinci pálos kolostor [The Pauline monastery in Budaszentlőrinc] (Budapest: Fővárosi Önkormányzat Kulturális Bizottsága, 1993), 7-9.

3. Emil Kisbán, A magyar Pálosrend története, 190. József Török, A magyar pálosrend liturgiájának forrásai, kialakulása és föbb sajátosságai, 1225-1600, II, 14-19.

4. Janka Szendrei, A magyar középkor hangjegyes forrásai [Notation Sources of the Hungarian Middle Ages] (=Műhelytanulmányok a magyar zenetörténethez 1) [Workshop Studies in Hungarian Music History 1] (Budapest: Institute for Musicology of the Hungarian Academy of Sciences, 1981), 34; eadem, "Hangjegyírás” [Musical Notation], in Magyarország Zenetörténete I. Középkor [Music History of Hungary, vol. I. Middle Ages], ed. Benjamin Rajeczky (Budapest: Akadémiai Kiadó, 1988), 230; eadem, Középkori hangjegyírások Magyarországon [Medieval Plainchant Notations in Hungary] (=Mühelytanulmányok a magyar zenetörténethez 4) (Budapest: Institute for Musicology of the Hungarian Academy of Sciences, 1999), 60.

5. Studies that deal with the retrospective Pauline plainchant tradition are Janka Szendrei, Graduale Romanum ad Usum monasterii de Újhely (1623), introduction by Janka Szendrei (Budapest: Institute for Musicology of the Hungarian Academy of Sciences, 2010) (=Musicalia Danubiana 24), 12-14; Gabriella Gilányi, "Retrospective or not? Pauline introits in 18th-century Hungary," in Der Paulinerorden: Geschichte, Geist, Kultur, hrsg. Sarbak Gábor (Budapest, Szent István Társulat, 2010) (=Müvelödéstörténeti Mühely. Rendtörténeti Konferenciák 4/2 [Cultural History Workshop. Conferences on the History of Orders 4/2], 503510; eadem, "A hiányzó láncszem? Egy 1687-es pálos antifonále Crikvenicából” [The missing link? A Pauline antiphoner of 1687 from Crikvenica], Magyar Zene 52/1 (2014), 5-15; eadem, "The Processional Oct. Lat. 794 of the Budapest National Széchényi Library. A re-identification," Studia Musicologica of the Hungarian Academy of Sciences. Plainchant Studies in memoriam of László Dobszay 56/2-3 (2015), 257-289; eadem, "A latin egyszólamú liturgikus ének Magyarországon a 18. században" [Latin plainchant in Hungary in the eighteenth century], in Zenei repertoár és zenei gyakorlat a 18. századi Magyarországon [Musical Repertory and Performance Practice in 18th-Century Hungary] (=Mühelytanulmányok a 18. század zenetörténetéhez 2), ed. Katalin Kim (Budapest: MTA Bölcsészettudományi Kutatóközpont, Zenetudományi Intézet, 2017), 91-128; eadem, "Archaizmusok és neologizmusok a pálos zsolozsmában" [Archaisms and neologisms in the Pauline office], in Zenei repertoár és zenei gyakorlat a 18. századi Magyarországon (=Mühelytanulmányok a 18. század zenetörténetéhez 2), ed. Katalin Kim (Budapest: MTA Bölcsészettudományi Kutatóközpont, Zenetudományi Intézet, 2017), 129-148. 
detailed analyses to be made. Although no complete Pauline gradual, for example, has survived from the Middle Ages, it is possible to study a large number of surviving codex fragments as sources of full value for paleographic analysis. These fragments in an ideal case condense within themselves all the important information on musical notation.

Yet despite these inspirations, no intrinsic examination of Pauline notation has been made. Janka Szendrei returned repeatedly to the Paulines in her pioneering monograph on chant notation of medieval Hungary, but without treating the subject as a whole. ${ }^{6}$ So, the Paulines appears in her synthesizing chapters on different periods of medieval Hungarian notation. It is true that evaluation of the Pauline notating tradition would remain incomplete without a knowledge of the general history and development directions of plainchant notation in Hungary. Moreover, two hundred years of prior history need fitting into it. At the same time, the need to write a separate history of Pauline notation is urged by the fact that its path later went a separate way at a separate speed: it departed and distanced itself from the model used by Esztergom. So there is good reason for doing comprehensive work on Pauline notation, but its starting point must be detailed examination, neume by neume. All that can be attempted in this study is an outline of the stages in the development, a division into periods, and some initial impressions of Pauline notation practice as a whole.

Janka Szendrei stated that the Pauline Fathers took the calligraphic Esztergom notation as their pattern in the fourteenth century. ${ }^{7}$ This notation was a peak achievement of Gregorian notation in Hungary. It was an exceptionally well proportioned, flexible and artistic style of writing even by European standards. ${ }^{8}$ This starting point of Pauline notation would suggest that those Paulines faithful to Esztergom used the actual Esztergom notation of their time.

The truth is that even the earliest surviving Pauline sources, from the end of the fourteenth century, fail to provide a valid picture of that actual Esztergom notation of their time. In fact the delicate calligraphic notation known from the Missale Notatum Strigoniense $e^{9}$ was anachronistic in Esztergom by the end of the fourteenth century, when the first Pauline sources appeared. It had fallen out of use in that specific form. By then the old flexible, curly Esztergom shapes had loosened and fragmented. The single notes were being marked and separated in attempts to meet new requirements for Gothic notation technique. The increase in the size of liturgical books and note heads in that period caused central workshops

6. Janka Szendrei, Középkori hangjegyírások Magyarországon, 60-61, 74-76.

7. See fotnoote 3.

8. The fourteenth-century calligraphic chant notation of Esztergom is comprehensively discussed by Janka Szendrei. See Szendrei, Középkori hangjegyírások Magyarországon, 58-60.

9. RISM-siglum: SQ-BRm EC Lad. 3. Facsimile edition with introduction: Janka Szendrei and Richard Rybarič eds., Missale Notatum Strigoniense ante 1341 in Posonio (=Musicalia Danubiana 1) (Budapest: Institute for Musicology of the Hungarian Academy of Sciences, 1982). 
to turn to a smarter, more regular and modern notating ideal. By this time the Messine-German type of Gothic notation popular in Central Europe had reached Hungary, giving rise to a unique blend of codex writing that Szendrei named the mixed Hungarian-Messine-Gothic notation system. ${ }^{10}$

So the notation in Esztergom in the late fourteenth century, found at the time of the earliest surviving Pauline sources, had already assimilated some new features differing from its own tradition. In Esztergom, the post-puncta, which follow each other in a strict vertical line, were gradually shifting to the right (Table 1), so producing enough place for each note on the staves and giving a spacious, transparent, comfortable picture more appropriate to a representative, large-scale choir book. While the approach was made to more modern musical notation by absorbing new Messine-German structural details, two important elements in earlier Hungarian chant notation had perished in Esztergom. The first loss, as we have seen, was the look of a concise, vertical series of notes beginning with double points. Secondly, the traditional direction of writing - a slant ascending to the right, then a vertical downward movement inside the neume structures - was replaced by a sliding descent. The copying practice of the Pauline notators, however, kept both the original direction of the writing and the characteristic double points of the climacus sign, even to the end of the eighteenth century. Indeed vertical point series starting with double points can be observed in all Pauline ligatures where the notes move downward in steps. It seems that the fourteenth-century Pauline notators were stuck in the past, just writing the same old Esztergom neumes with thicker (Gothic) pen-strokes and retaining the inner structures of the neumes intact. Based on this chronological lag and discrepancy, it is possible to distinguish the notations of the contemporary Pauline and Esztergom workshops and identify fragments that are of Pauline origin even where the sources contain no such characteristic liturgical elements.

The basis for systematic discussion of Pauline notation used here is the historical time-line or age of the sources, starting at the outset. Although the organization events of the Pauline Order began in the thirteenth century, it did not achieve before the early fourteenth century a sufficient state of material or organizational security for official scriptoria to exist in its houses. The Paulines used Esztergom books until the beginning of the fifteenth century, when their mother church of Budaszentlörinc ${ }^{11}$ and the more important vicarial houses had gained, for example, sufficient skilled copyists for the task. ${ }^{12}$

10. Janka Szendrei, Középkori hangjegyírások Magyarországon, 63-68.

11. Emil Kisbán, A magyar Pálosrend története [History of the Hungarian Pauline Order] (Budapest: Pálos Kolostor Kiadása, 1940), I, 73. Zoltán Bencze-György Szekér, A budaszentlörinci pálos kolostor, 9.

12. Gábor Sarbak, "Pálosaink írásbelisége a középkor végén" [Pauline literacy at the end of the Middle Ages], online: http://vigilia.hu/regihonlap/2001/2/sar0102.html (last accessed: March 31, 2018). Janka Szendrei, Középkori hangjegyírások Magyarországon, 74. 
TABLE 1 Transformation of the "climacus" sign in the late Esztergom notation
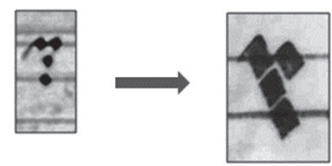

c. 14

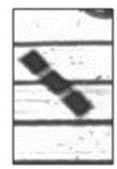

c. 15
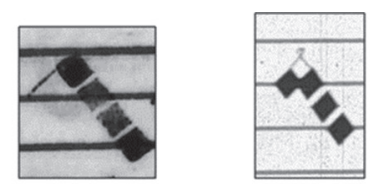

Change of writing directions
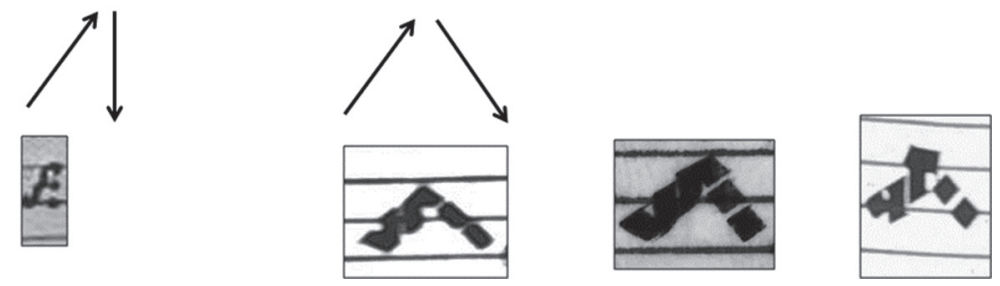

For as stated before, the Paulines, in their closed, puritanically inclined environment, developed a musical notation quite different in dynamics and purpose from the main Esztergom tradition, which had to serve the demands of high clergy for formal display. Initially, in the fourteenth century, when Pauline organized life had scarcely begun, it may have taken decades before the musical notation could be practised or fully introduced. There is no telling how the earliest Pauline musical notation looked, as no contemporary source has survived, but it can be imagined that it was less mature than that of Esztergom at the beginning of the fourteenth century, judging by the Missale Notatum Strigoniense, ${ }^{13}$ which dates from the first half of that century.

So what early Pauline sources can be examined? Three of the earliest mentioned in the literature are two fragments and a missal from the end of the fourteenth century. One, known as the Boldogkőváralja fragment, ${ }^{14}$ was found in 2003 in the small north-east village of Halmaj, Borsod County, but adventurous research done there also revealed that the fourteenth-century fragment described by Kilián Szigeti as Pauline is actually inscribed in Bohemian notation, so that a Pauline provenance can be excluded. However, the examples in Janka Szendrei's monograph of notated sources - the F 333 fragment in the Hungarian National Archives in Budapest ${ }^{15}$ (Facsimile 1) and the Pauline missal from Göttweig

\section{See Note 7.}

14 From a Breviarium Notatum. See Kilián Szigeti, „Denkmäler der Gregorianischer Chorals aus dem ungarischen Mittelalter", Studia Musicologica 6 (1963), 158.

15. This is a Graduale fragment in the National Archives of Hungary, E 159/1571/25 Comit. Zemplén. F 333 (For fragments with F abbreviations, see Janka Szendrei's catalogue, A magyar középkor hangjegyes forrásai, 59-122). 
(M 46) from the end of the fourteenth century ${ }^{16}$ - really do contain Esztergom notation, and to present knowledge can be considered the earliest surviving Pauline sources. They have been inscribed carefully and concisely in flexible, continuous, rolling neumes, as in the calligraphic Esztergom style, but their details are joined by thick pen lines (single basic neumes as they appear in the earliest medieval Pauline manuscripts, see Table 2).

The notes are not marked separately: the punctum (syllabic basic element) is rhomboid, and the pes and clivis have thin, clear, curving entry lines. It is worth noting also the S-shaped pes signs, whose entry lines often form a hook. Still more important is that the writing shows typical basic Esztergom neumes: the climacus with double points and the conjunct form of the same, ${ }^{17}$ the conjunct scandicus drawn with a single line, and the likewise single-line torculus and porrectus signs, which again allude to the calligraphic Esztergom notation. Yet even the earliest documented Pauline sources display two elements that appear to be developments original to Pauline notation. One is that each element in the Esztergom notation begins to thicken with the Paulines, without any alteration in the structure of the notation or character of the neumes. So the signs are magnified, not the individual notes within them, as if this were an exaggerated, almost didactic variant of Esztergom notation, or to make a modern comparison, a bold-face version of it. The other Pauline feature, to which Szendrei drew attention, is the characteristic post-puncta in the climacus, which begins with double points It is important to note that the use of two entry points to the neume is not a consistent editing principle in fourteenth-century calligraphic notation from Esztergom (where a single point is often found), and it does not become the exclusive form in later centuries either, whereas in Pauline notation it remains characteristic throughout, used wherever possible.

To continue chronologically, scholars seldom emphasize sufficiently that a new chapter in Pauline notation opened in the fifteenth century. There was rapid development in culture and writing, due to the prosperity of Pauline religious life and the donations and privileges received from Hungarian patrons. ${ }^{18}$ The inward and outward appearance of the Pauline liturgical books was transformed by an ornamental, larger-format manuscript type introduced for the liturgical choir (Facsimile 2-3). ${ }^{19}$ By the fifteenth century, the Paulines seem to have become practised musical notation, for other changes appear alongside the thickened writing. Their notators aimed at developing a fifteenth-century ornamental chant notation, taking as their main model the rhomboid style of mixed Hungarian-Messine-Gothic notation, which

16. M (=Missal) 46 (in the Szendrei catalogue): Pauline Missale, Göttweig, Monastic Library, Cod. 107. Some folios of the Holy Week liturgy appear with early Pauline musical notation (f. 79v, 87v, 93v).

17. The poorly notated Göttweig missal unfortunately has no example of this conjunct climacus.

18. The order was protected and donated by many Hungarian monarchs and Houses in the Middle Ages, eg. Béla IV (Árpád House), Charles Robert, Sigismund, Louis I the Great (House of Anjou), Matthias (House of Hunyadi). See Emil Kisbán, A magyar Pálosrend története, I, 72-74.

19. Janka Szendrei, Középkori hangjegyírások Magyarországon, 74-76. 
FACSIMILE 1 14th-century example of Pauline notation

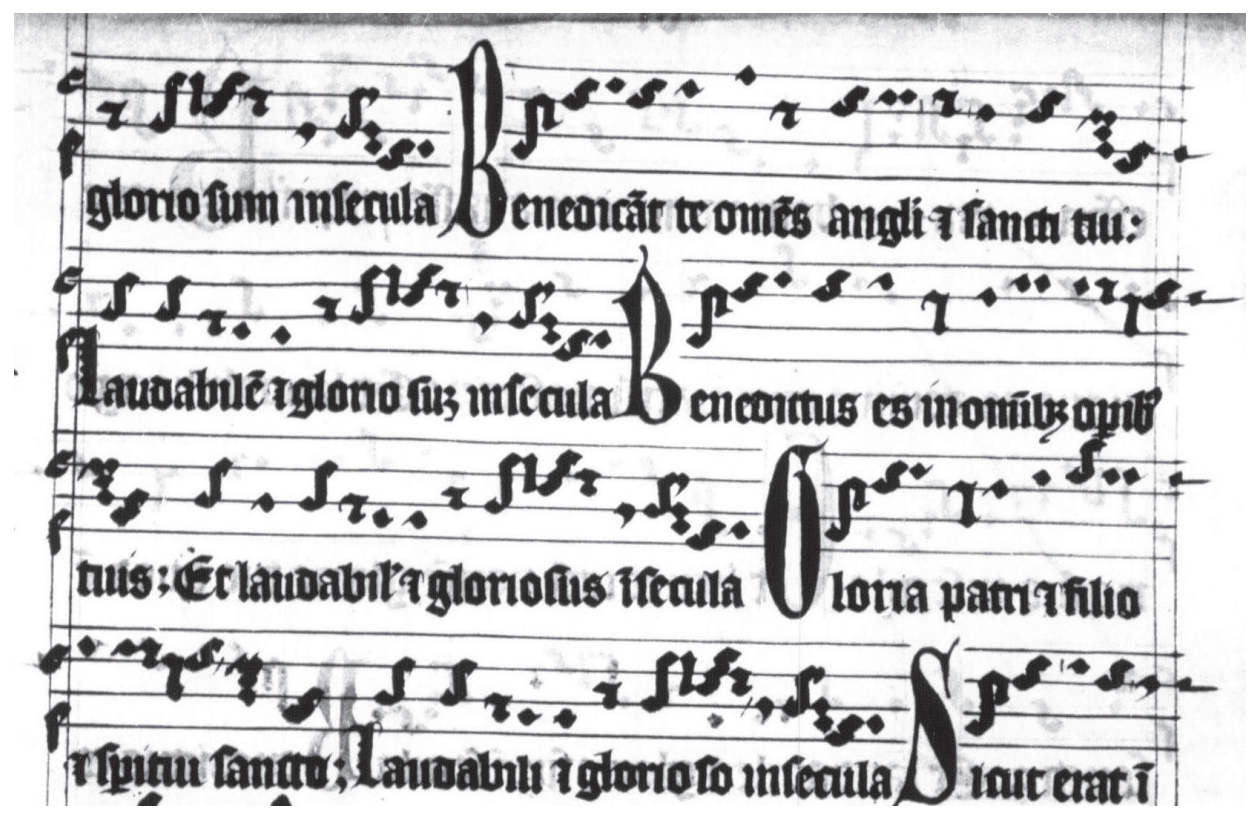

TABLE 2 Earliest examples of the Pauline notation

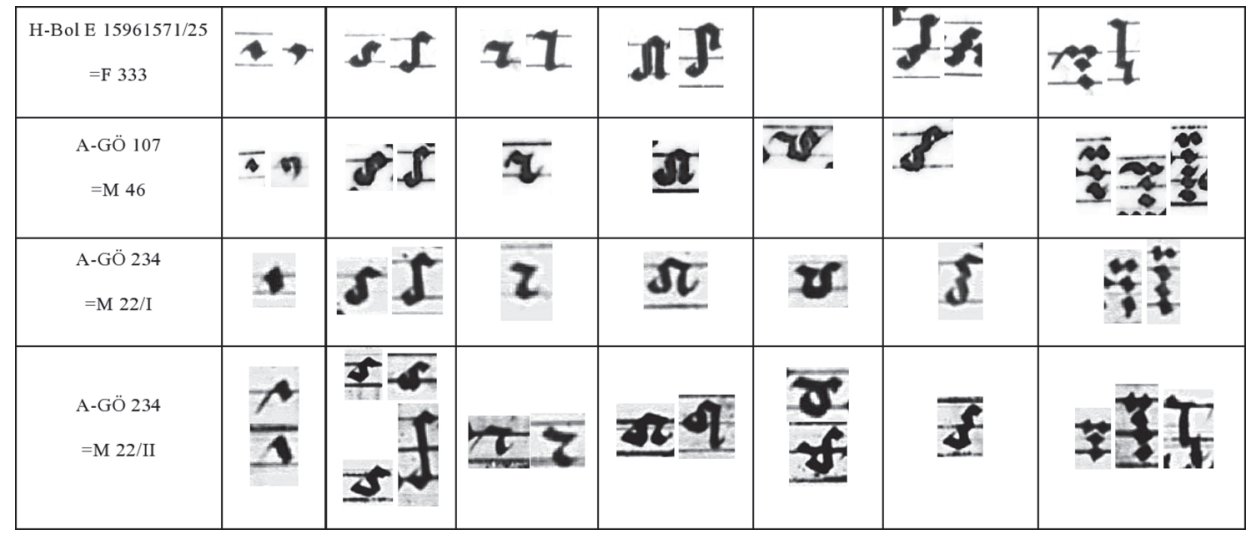

can be examined comprehensively in the musical writing of the Pauline gradual fragment preserved in the Library of the Hungarian Academy of Sciences. ${ }^{20}$

20. Magyar Tudományos Akadémia Könyvtára [Library of the Hungarian Academy of Sciences], T 292. See Kinga Körmendy, "Egy XV. századi magyarországi graduale" [A fifteenth-century Hungarian Graduale], Magyar Könyvszemle 90/1-2 (1974), 111-115; eadem, A Knauz-hagyaték kódextöredékei és az esztergomi egyház középkori könyvtárának sorsa [Codex Fragments of the Knauz-collection and the fate of the medieval ecclesiastical library of Esztergom] (=MTAK Közleményei. Új sorozat 7) (Budapest: Magyar Tudományos Akadémia Könyvtára, 1979), 78. 
Facsimile 2. Pauline antiphoner fragment in the Pauline Library of the Central Seminar of Budapest, S. Fr. 1. m. 103

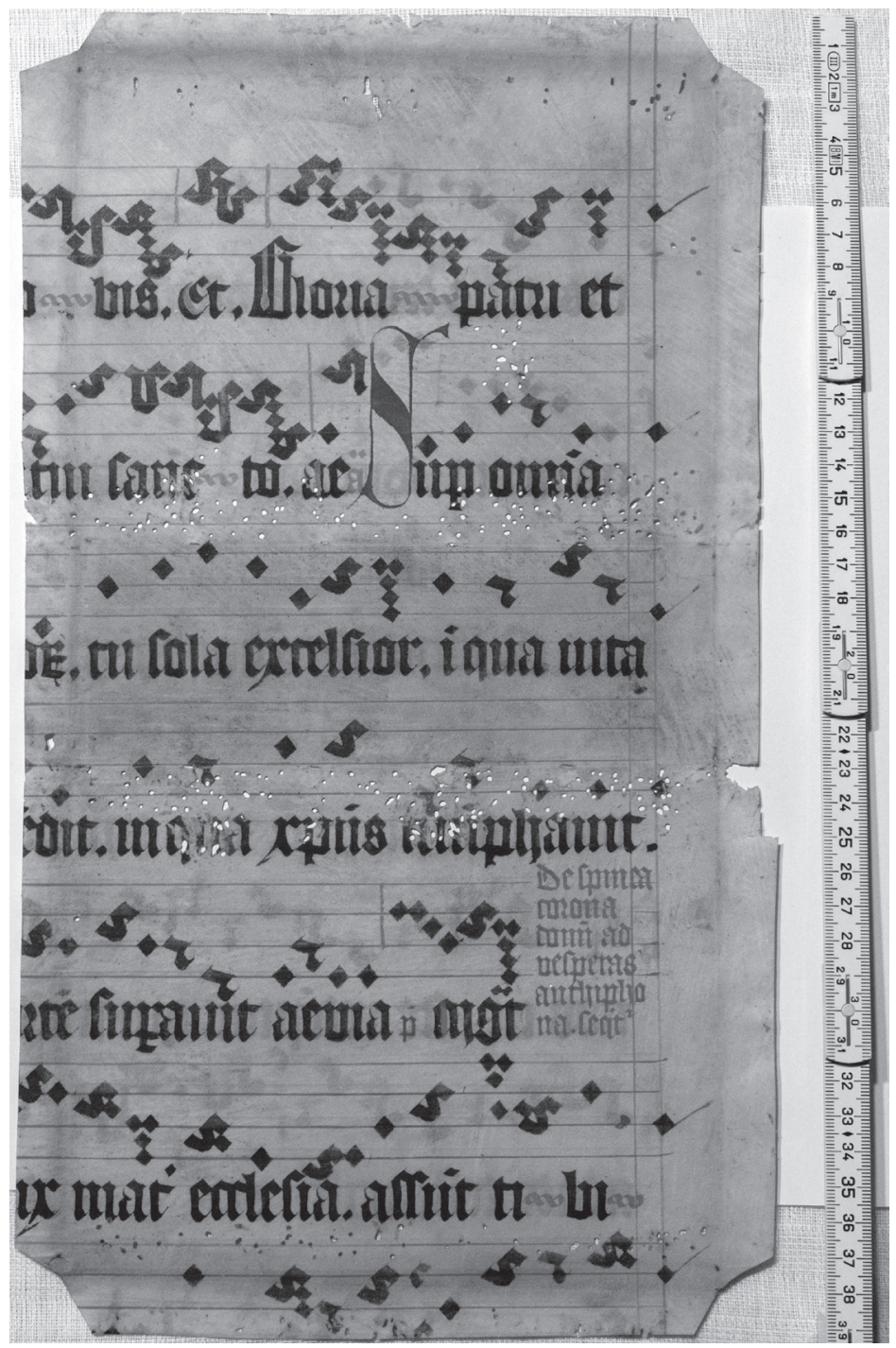

On inspecting the Pauline neumes of the time, it appears that the development was very rapid and clear. On the one hand, traditional signs were kept in use (e. g. special forms for the pes, clivis, climacus and scandicus), and on the other the appearance of the codices becomes more standardized and intelligible (Table 3-4).

The size of the signs again increases, but the effort now goes into emphasizing the individual notes, and it can be seen that flexible elements in them yield to straight lines and angles. Let us see, for example, the shape of the torculus 
Facsimile 3 Pauline gradual fragment in the Pauline Library of the Central Seminar of Budapest, S. Fr. 1. m. 122

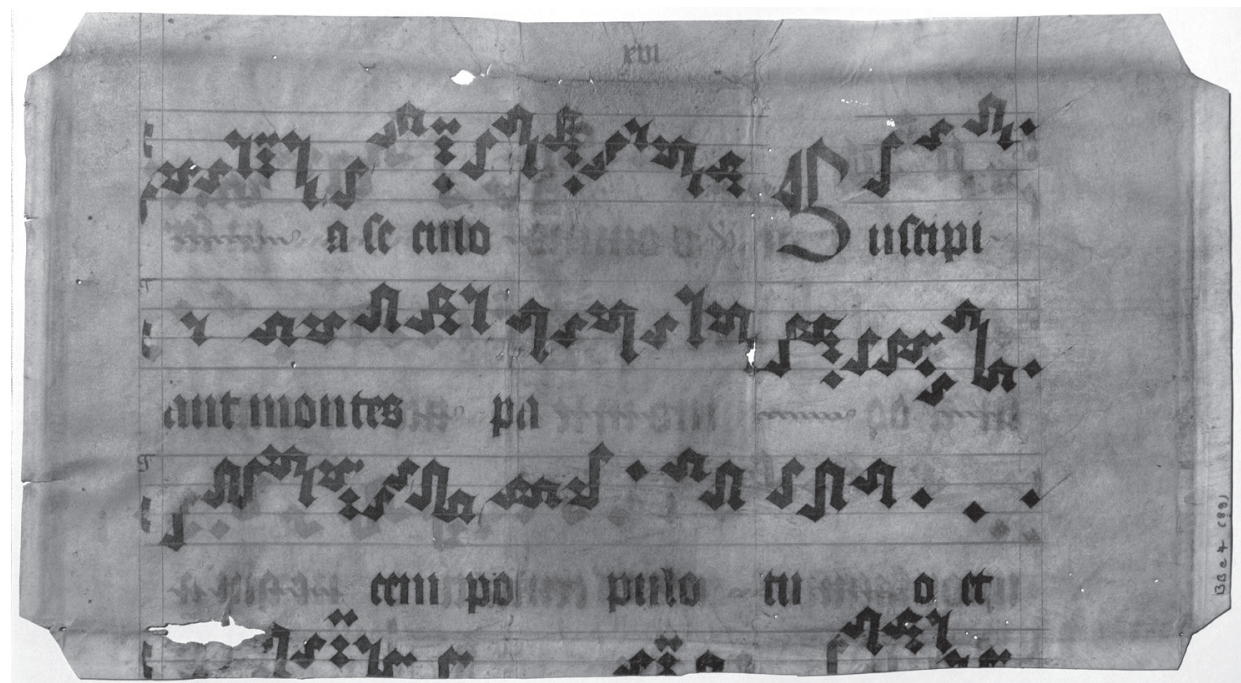

neume that consists of three notes (Table 5). In the early Pauline sources, the torculus consists a single pliable, curly line without any square or discontinuity in its shape, as was applied in the earlier calligraphic Gregorian notation of Esztergom. In the early $15^{\text {th }}$ century handwriting of the Pauline Missal of Göttweig, however, an increasingly angled form of the torculus can be seen. This may be considered a deliberate change aimed at emphasizing the second note in the sign. Yet it proved to be only the first step in a process. During the fifteenth century, the torculus neume became more and more angular, so bringing about an isolation of the

TABLE 3 15th-century "rounded" type of Pauline notation

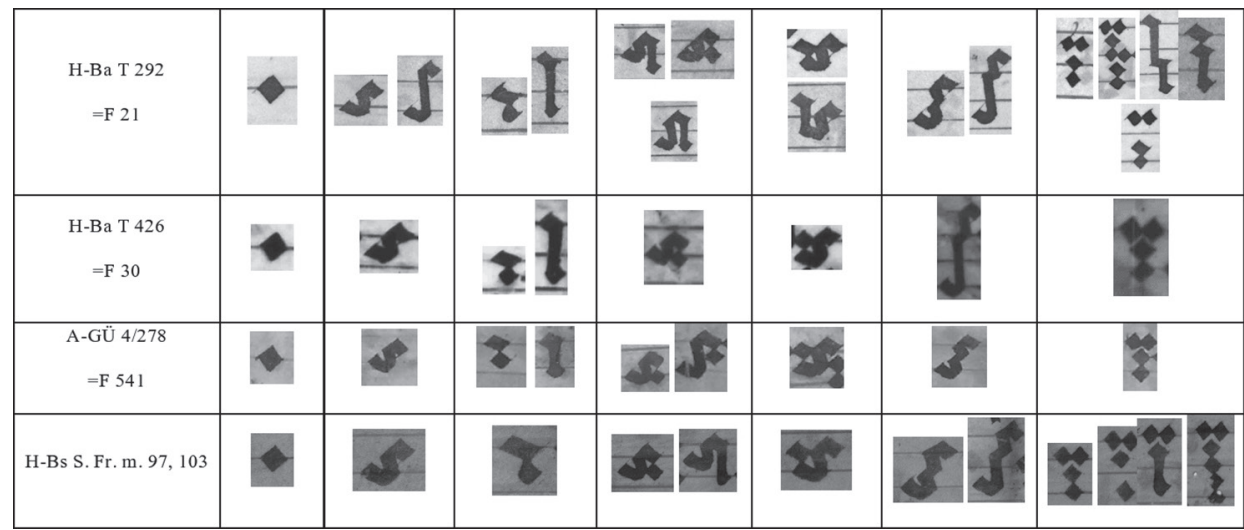


TABLE 4 15th-16th-century "angular" type of Pauline notation

\begin{tabular}{|c|c|c|c|c|c|c|c|}
\hline H-SA 888 Fr. 17 & $\nabla$ & 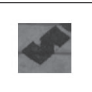 & 1 & & & 3 & \\
\hline $\begin{array}{l}\text { SK-BRsa AnV.N. } 197 \\
\text { Nr. } 13 .\end{array}$ & $\Delta$ & $\Delta$ & $y$ & An & 2 & 5 & 12 \\
\hline 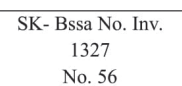 & I & $\$$ & $y$ & 4 & 4 & 1 & है \\
\hline H-Bs S. Fr. m. 90 & $\downarrow$ & 5 & $x$ & ar & & & \\
\hline 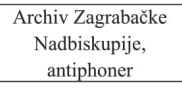 & 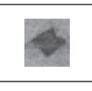 & 5 & 82 & 8 & 2 & $s^{5}$ & 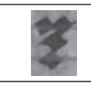 \\
\hline 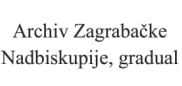 & 1 & 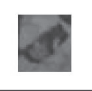 & 엉 1 & N & 8 & (1) & 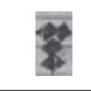 \\
\hline
\end{tabular}

\begin{tabular}{|c|c|c|c|c|c|c|c|}
\hline 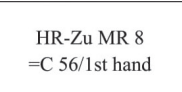 & 4 & 5 & $y$ & 2 & 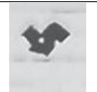 & 5 & s \\
\hline 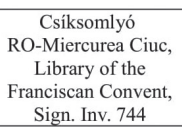 & - & 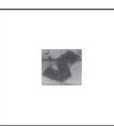 & x & 4 & it & 1 & \\
\hline 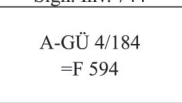 & - & 国 & 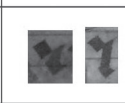 & & 20 & A & \\
\hline 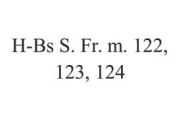 & 1 & A & & 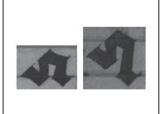 & 8 & 14 & \\
\hline 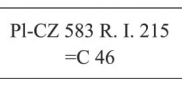 & 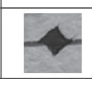 & + & $x$ & A & r & Ms & \\
\hline
\end{tabular}

notes. Finally, the separation of the third note can be considered a new element, as it was connected to the preceding note only by one common point.

The punctum was transformed into an angular rhombus, and the unit appears after a time separately, without an entry stroke. All parts of the "S" shape of the pes become angular, notes and joining lines alike. Moreover the first element of the punctum becomes slightly elongated, especially in the more cursive type of Pauline musical writing. The same shift can be seen in the clivis for a second step: the first member lengthens and the second tends to move under the lengthened first from the right-hand side of the neume. In the climacus, it becomes increasingly hard to place the enlarged notes one under the other, and so the elements are pressed together, as the notators insisted on a vertical direction and did not allow the note sequences to slant to the right. The change in the scandicus follows the same direction, so that the flexible fourteenth-century form 
TABLE 5 Development of the Pauline torculus in the 14th -15th century

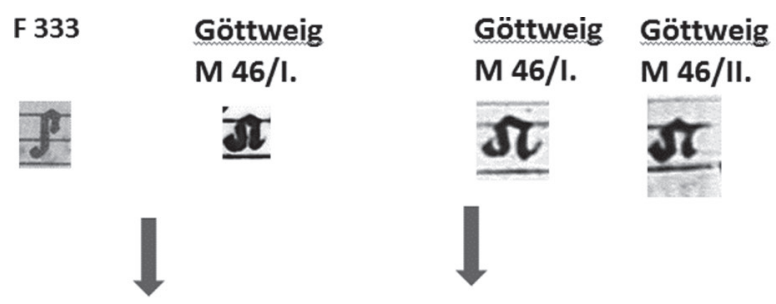

\section{later}
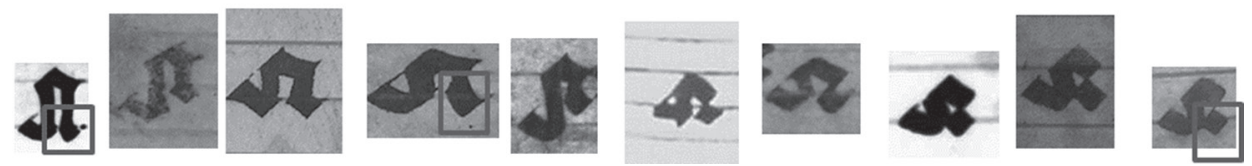

TABLE 6 Transformation of scandicus in the 14th-18th centuries

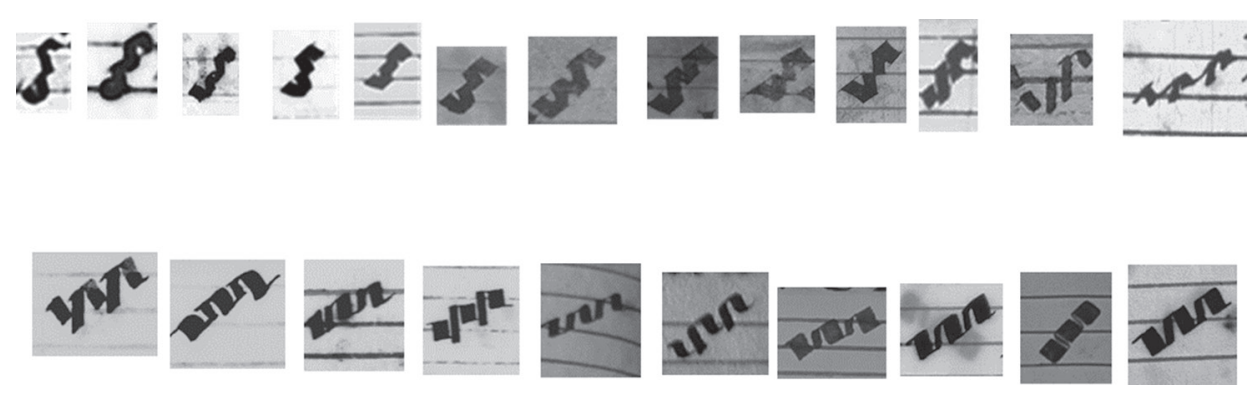

arrives by the fifteenth century at neume shapes consisting of separate angular lines (Table 6).

All in all, this ornamental Pauline chant notation can be treated as a normative Pauline style of music writing that differs markedly from every other Hungarian type of notation, and helps in identifying sources. This observation is confirmed by some newly discovered Pauline fragments from the fifteenth-century source group. Preserved in the Library of the Reformed-Church College in Sárospatak, book-cover fragment number 17 must be considered to be Pauline on the basis of paleographic analysis, although investigation of the liturgical content does not provide enough information as to its provenance. Another parchment fragment, a hymnal containing Pauline notation, was found in Zagreb National and University Library on a visit made in 2010. ${ }^{21}$ As a binding of an eighteenth-century Pauline Processionale Romanum from Lepoglava, its Pauline origin is proven. A dozen Pauline codex fragments (deriving from a gradual and antiphoner) were identified

21. This is a fifteenth-century binding of a Processionale from Lepoglava, 1753 (siglum: R 3612). 
in 2010 in the Archiepiscopal Archive in Zagreb. ${ }^{22}$ Also found were Pauline fragments in the abundant collection at the library of the Franciscan House in Güssing, ${ }^{23}$ and a further remarkable group of 15 th-century Pauline fragments emerged in the Pauline Library of the Central Seminar in Budapest. ${ }^{24}$ There, altogether 7 Pauline fragments were found from the fifteenth century: ${ }^{25}$ three derived from the same gradual, a book type of which no complete Pauline example from the Middle Ages has survived. Some years ago, further notated codex fragments were discovered by Eva Veselovska in Slovakian collections, ${ }^{26}$ and new Pauline fragments have emerged from Transylvania as well. ${ }^{27}$

Studying this enormously increased number of fifteenth-sixteenth-century Pauline sources allows some new conclusions to be drawn. The latest paleographical analysis revealed in the sources two clearly distinguishable musical codex-writing styles: a flexible - transitional - form with pliable elements, rooted in the earlier Esztergom notation (see Facsimile 2 and Table 3), and an expressly angular form, recalling the musical writing of the large Gothic choir books as a pattern (Table 4 and Facsimile 3). Use of this type depends, on the one hand, on the age of the source. Earlier books were notated in a more archaic fluent manner (Table 7a), but at the end of the fifteenth century, regularly professional, rhomboid neumes and rigid structures were preferred (Table $7 b$ ), while sources from the mid-century tended to show a more flexible Gothic hand enriched by softened strokes, delicate entry lines and rounded forms. See, for example, the gradual fragments in the Library of the Hungarian Academy of Sciences, the parchment codex pieces No. 97 and 103 at the Pauline Library (Facsimile 3), or the Pauline gradual fragment in Güssing. ${ }^{28}$ Another group of sources (probably from the end

22. Pieces of a Pauline antiphoner and gradual emerged in Collectio fragmentorum in the Archiv Zagrabačke Nadbiskupije, without signs. See Andrea Kovács, "Középkori hangjelzett töredékek Zágrábban" [Medieval notated fragments in Zagreb], Magyar Egyházzene 16 (2008/2009), 271-276, here: 271-272.

23. Library signs: 4/35, 4/184, 4/278.

24. Gabriella Gilányi, „Középkori kottás töredékek újrafelfedezése a Központi Papnevelő Intézet Pálos Könyvtárában" [Rediscovery of medieval notated fragments in the Pauline Library of the Central Seminar in Budapest], in Kiss Gábor (ed.), Zenetudományi dolgozatok 2012 (Budapest: MTA BTK Zenetudományi Intézet, 2014), 389-393.

25. Pauline notation can be seen on fragments no. 90, 97, 103, 122, 123 and 124. See László Mezey et soc., Fragmenta Latina codicum in Bibliotheca Seminarii Cleri Hungariae Centralis (=Fragmenta codicum in bibliothecis Hungariae I/2) (Budapest: Akadémiai Kiadó, 1988).

26. Eva Veselovská, Catalogus fragmentorum cum notis musicis medii aevi - Archivum Nationale Slovacum. Tomus III (Bratislava: Institute für Musikwissenschaft der Slowakischen Akademie der Wissenschaften, 2014), No. 13, Graduale, Inv 197, Graduale, 1 folio (recto/verso); eadem, Catalogus fragmentorum cum notis musicis medii aevi - Catalogus fragmentorum cum notis musicis medii aevi e civitate Schemnitziensi. Tomus II (Bratislava: Institute für Musikwissenschaft der Slowakischen Akademie der Wissenschaften, 2011) No. 56 Missale, Inv 1327.

27. Zsuzsa Czagány, Erzsébet Muckenhaupt and Ágnes Papp, Liturgikus és kottás középkori kódextöredékek a csíksomlyói ferences könyvtár egykori könyvtárának állományában [Liturgical and notated medieval codex fragments in the old stock of the Franciscan Library of Csíksomlyó] (=Csíki Székely Múzeum Évkönyve 2005, Társadalom- és Humántudományok; Csíkszereda: Csíki Székely Múzem, 2006), Cz. Fr. 11 (Sign. Inv. 744).

28. Library of the Franciscan Convent, Stell 4/278. 
TABLE 7A-B
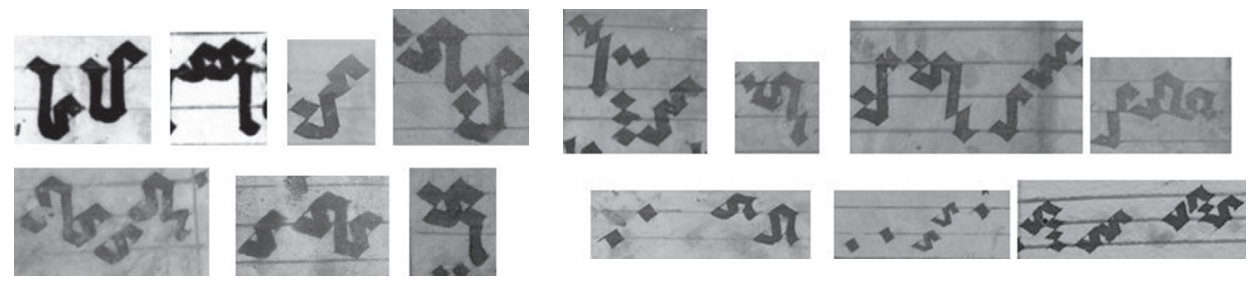

of the fifteenth century or later) are highly standardized and followed a disciplined, artificial calligraphy. As with the monumental Esztergom-Buda choir codices of the time ${ }^{29}$ sharp and angular elements dominate these Pauline sources, without of the slightest sign of the fluent elegance of earlier times (Table $7 b$ ).

On the other hand, another level of differentiation can also be grasped based on the source studies. Despite the intense centralization and traditionalism of the Pauline notational practice from the beginning, it seems to be possible to identify some geographical variants among the late medieval Pauline musical writings. Pauline sources, which could come from the northern and North-East part of the country and from the southern peripheral area, probably received direct impetus from the local diocesan scriptoria found there. The horizontally elongated elements of the pes and clivis, strongly angled note and stroke forms, the special scandicus, which may remind us of "saw-teeth" and horizontal conjunct neume combinations (Table $7 b$ ) tell a lot about this inspiration..$^{30}$ This Pauline chant notation is recognizable of the enlarged single rhomboid points-series and its smaller-sized, linearly elongated neume-compositions, in which thinner linking lines and elongated note-heads appear. These structures are created from mainly linear elements instead of large separate rhomboid headnotes. The group of sources using this notation, also include the Częstochova Cantuale, furthermore, the same angular, and size-changing Pauline notation can be seen on the sixteenth-century fragment from Zemplén, North-Hungary or in the Upper-Hungarian region, whose sources are kept in Slovakian collections now. We also know close parallels from Transylvanian and Zagreb examples. ${ }^{31}$

29. Gabriella Gilányi, "Használatitól a műremekig: a 15. századi hangjelzett esztergom-budai kódexek" [From ordinary to masterpiece: the fifteenth-century notated Esztergom-Buda codices], in Gabriella Gilányi (ed.), Zenetudományi dolgozatok 2015-2016 (Budapest: MTA BTK Zenetudományi Intézet, 2018), 24-36.

30. A line-structured fifteenth-century musical script can be considered as a musical writing type on the peripherical areas of medieval Hungary. We could pointed it out from Upper-Hungary, Transylvania, Zagreb. See F 174, F 337, F 34 and 328, F 586 etc. fragments in Janka Szendrei's catalog.

31. Lately I have noticed another interesting group among "Pauline" fragments with this kind of notation (H-Bs S. Fr. m. 120, H-Bu Fr. 1. m. u. 221, A-GÜ 4/184), but the Pauline origin of them seems to be uncertain regarding their contradictory liturgical content. Further inspections are needed to reveal these sources' real provenance. 
TABLE 8 Cursive notation in 16th-17th-century Pauline manuscripts

\begin{tabular}{|c|c|c|c|c|c|c|c|}
\hline $\begin{array}{c}\text { PI-CZ } 583 \text { R. I. } 215 \\
=\text { C } 46\end{array}$ & $\approx$ & if & 2 & oq & ar & $u^{5}$ & 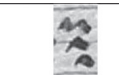 \\
\hline $\begin{array}{c}\text { H-Bn Clmae } 253 \\
=\text { = } 35\end{array}$ & $\bullet$ & $\boldsymbol{f}$ & $\tau$ & of & if & If & 77 \\
\hline $\begin{array}{l}\text { H-Sa sine sign. } \\
\quad=\mathrm{C} 77\end{array}$ & 7 & at & $\tau$ & m & $\pi$ & $\overline{p^{n}}$ & 米立 \\
\hline
\end{tabular}

An important stage in Pauline notating tradition was the way the ornamental style seen above departed from a cursive version of musical notation used for practical purposes. ${ }^{32}$ Discussion of the sixteenth century would be incomplete without examining this practical notation used in parallel with the ornamental at first. On the one hand the Pauline and the Esztergom styles reach a common point again in cursive writing practice, on the other, this type of notation is the one that allowed the Pauline order to retain the continuity of its musical tradition to survive later, after the Ottoman conquest and the devastations of the Reformation (Table 8).

Hungarian musical notation for practical purposes, e. g. for school education, ${ }^{33}$ is rooted in calligraphic Esztergom notation, characterizing the whole Hungarian area. Its practical function and consequent incidental nature mean that its use produces a strongly subjective setout, so that it becomes impossible to distinguish the Pauline and Esztergom/or other Hungarian variants of it. Cursive notation is typical in the sixteenth-seventeenth centuries of types of books in which music is of secondary importance, for example Missals with musical additions and special collections of chants (cantuale, cantionale) that began in the fifteenth century to serve liturgical purposes (Facsimile 4). Besides, cursive chant notation was also applied in scanty liturgical books after 1525, when Ottomans destroyed the institutions of the Hungarian Catholic Church together with its prosperous codex art. In the cursive notation also appears the elements of the modern Messine-Gothic style of writing: the structures become increasingly loose and fragmented (Table 4). This fragmented nature of cursive Pauline notation may also has an impact on the Pauline ornamental style: this appears in the disintegration of the form of scandicus neumes (see earlier in Table 6).

The Hungarian church had to be rebuilt on new foundations after the historical cataclysms of the sixteenth-seventeenth centuries. The central Hungarian church

32. Janka Szendrei, Középkori hangjegyírások Magyarországon, 80-84.

33. Hungarian cursive notation can be seen in the school notes of the young László Szalkai (later archbishop of Esztergom) from Sárospatak, North-East Hungary. The Codex Szalkai (1489-1490) manuscript is preserved in the Archbishopric Library of Esztergom, II.395 (Janka Szendrei: C 11). See Dénes Bartha ed., Szalkai érsek zenei jegyzetei monostor-iskolai diák korából, 1490 [Musical notes of archbishop Szalkai from his monastery school-student years] (Budapest: Országos Széchényi Könyvtár, 1934); László Dobszay, "Szalkai László jegyzetének zenei példaanyaga" [Musical examples from the school notes of László Szalkai], in Zenetudományi dolgozatok 1980 (Budapest: MTA Zenetudományi Intézet, 1980), 215- 221. 
Facsimile 4 Cursive Pauline notation in the Czeştochowa Cantuale, p. 387

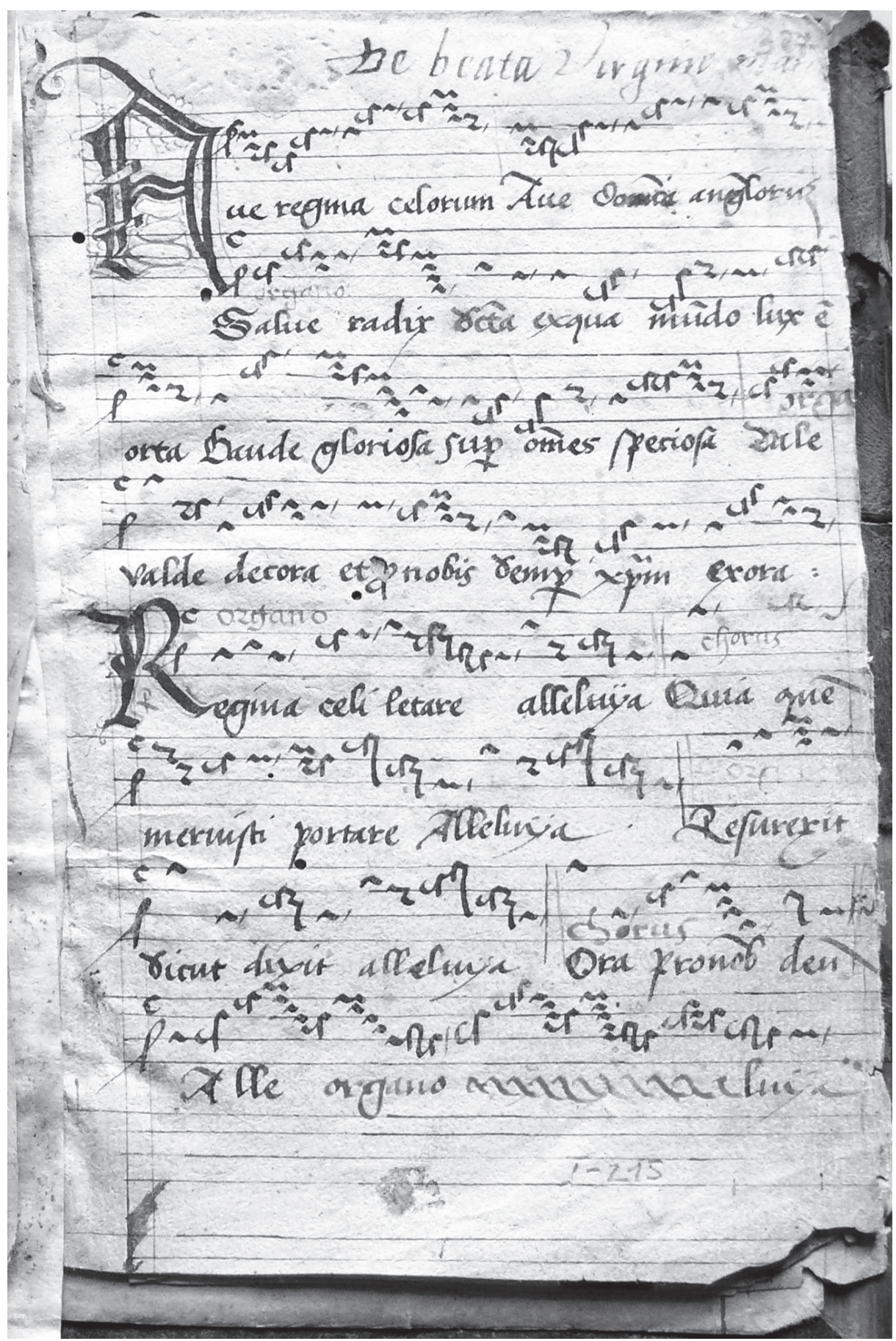


TABLE 9 Neumes in 17th-18th-century retrospective Pauline plainchant manuscripts a) 17 th-century sources

\begin{tabular}{|c|c|c|c|c|c|c|c|}
\hline & punctum & pes & clivis & torculus & climacus & scandicus & porrectus \\
\hline $\begin{array}{c}\text { Proc., } 1644 \\
\text { H-Bn Oct. Lat. } \\
794\end{array}$ & 4 & $\pi^{2}$ & $x$ & +4 & & & $x^{\prime \prime}$ \\
\hline $\begin{array}{c}\text { Grad., c. } 17 \\
\text { H-Bn Ms. Mus. } \\
7240\end{array}$ & 4 & +1 & & b. & & M & \\
\hline $\begin{array}{l}\text { Grad., } 1623 \\
\text { H-Bu A } 115\end{array}$ & $\uparrow$ & $\omega \sqrt{1}$ & $y$ & at & 4 & ant & $M$ \\
\hline $\begin{array}{c}\text { Ant., } 1688 \\
\text { HR-Zu R } 3038\end{array}$ & $\downarrow$ & 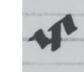 & $x$ & $A$ & * & $\sqrt{N^{2}}$ & $x$ \\
\hline $\begin{array}{c}\text { Ant., c. } 17 \\
\text { HR-Zmk MR } \\
178\end{array}$ & 1 & $a^{2}$ & $t_{1}$ & $\sqrt{1 / 4}$ & Th & $x^{2}$ & $\left.||_{1}\right|^{2}$ \\
\hline
\end{tabular}

b) 18th-century sources from the Croatian province

\begin{tabular}{|c|c|c|c|c|c|c|c|}
\hline $\begin{array}{c}\text { Proc., } 1753 \\
\text { HR-Zu R } 3612\end{array}$ & 1 & $\sqrt{1}$ & 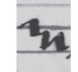 & $\sqrt{4}$ & & $\sqrt{11}$ & he \\
\hline $\begin{array}{l}\text { Vesp., } 1769 \\
\text { H-Bu A } 116\end{array}$ & $I$ & th & 4 & $\pi$ & $\frac{4}{4}$ & an & 4 \\
\hline $\begin{array}{c}\text { Ant., C. } 18 \\
\text { HR-Zu R } 3004\end{array}$ & 1 & $\nabla^{2}$ & 4 & Int & it & $\sqrt{4}$ & two \\
\hline $\begin{array}{c}\text { Ant, } 1738 \\
\text { H-Ek } 300897\end{array}$ & 1 & 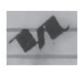 & the & $\sqrt{N_{2}}$ & & & 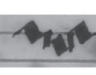 \\
\hline $\begin{array}{c}\text { Grad., } 1746 \\
\text { H-Bu A } 125\end{array}$ & 1 & N & the & whe & $x$ & 4 & Whe \\
\hline
\end{tabular}

c) 18th-century sources from the Croatian province

\begin{tabular}{|c|c|c|c|c|c|c|c|}
\hline $\begin{array}{c}\text { Kyr., } 1763 \\
\text { H-Bu A } 127\end{array}$ & & $\sqrt{2}$ & 4 & $\sqrt{4}$ & $x+\frac{1}{2}$ & 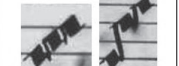 & thit \\
\hline $\begin{array}{c}\text { Ant., c. } 18 \\
\text { H-Es 2-4-3/686 }\end{array}$ & & & $4:$ & Vhe & & & in \\
\hline $\begin{array}{c}\text { Grad., } 1748 \\
\text { H-Ek } 300886\end{array}$ & & & & & & (1) & जir \\
\hline $\begin{array}{c}\text { Ant, } 1738 \\
\text { H-Ek } 300897\end{array}$ & & Nr & the & NM & & & than \\
\hline $\begin{array}{l}\text { Grad., } 1746 \\
\text { H-Bu A } 125\end{array}$ & & $\sqrt{2}$ & 4 & Wh & $4 \%$ & 6 & the \\
\hline
\end{tabular}


broke with its medieval traditions in line with the Counter-reformation aims of Archbishop Péter Pázmány of Esztergom, but the Paulines could continue their traditions of liturgical music and notation. ${ }^{34}$ Books for practical use in cursive chant writing were an attempt to rescue some of the medieval tradition, but that was not the last stage in the history of Pauline notation. Uniquely in Europe, there followed in the seventeenth-eighteenth centuries a further restyling of the notation, occurring visibly in two stages. Notation in seventeenth-century Pauline sources such as Graduale Romanum de Újhely, the newly found Crikvenica Antiphoner ${ }^{35}$ and the re-identified Pauline Processional from $1644^{36}$ and a Gradual of Pauline origin kept in the National Széchényi Library ${ }^{37}$ (Facsimile 5) goes beyond the improvised shorthand form into articulated signs again. The neumes show the traditionally attractive, proportionate appearance of Pauline notation, and above all, the distinguishing elements of Hungarian notation see Table 9.

Nor is that the end. Pauline notation in the eighteenth century proved capable of further renewal. Compared with that of the seventeenth century, the notation has an ornamental style of more abundant, restyled neumes using thinner lines, to

FACSIMILE 5 17th-century retrospective plainchant notation: National Széchényi Library,

Budapest, Music Collection, Ms. Mus. 7240, f. 2v-3r

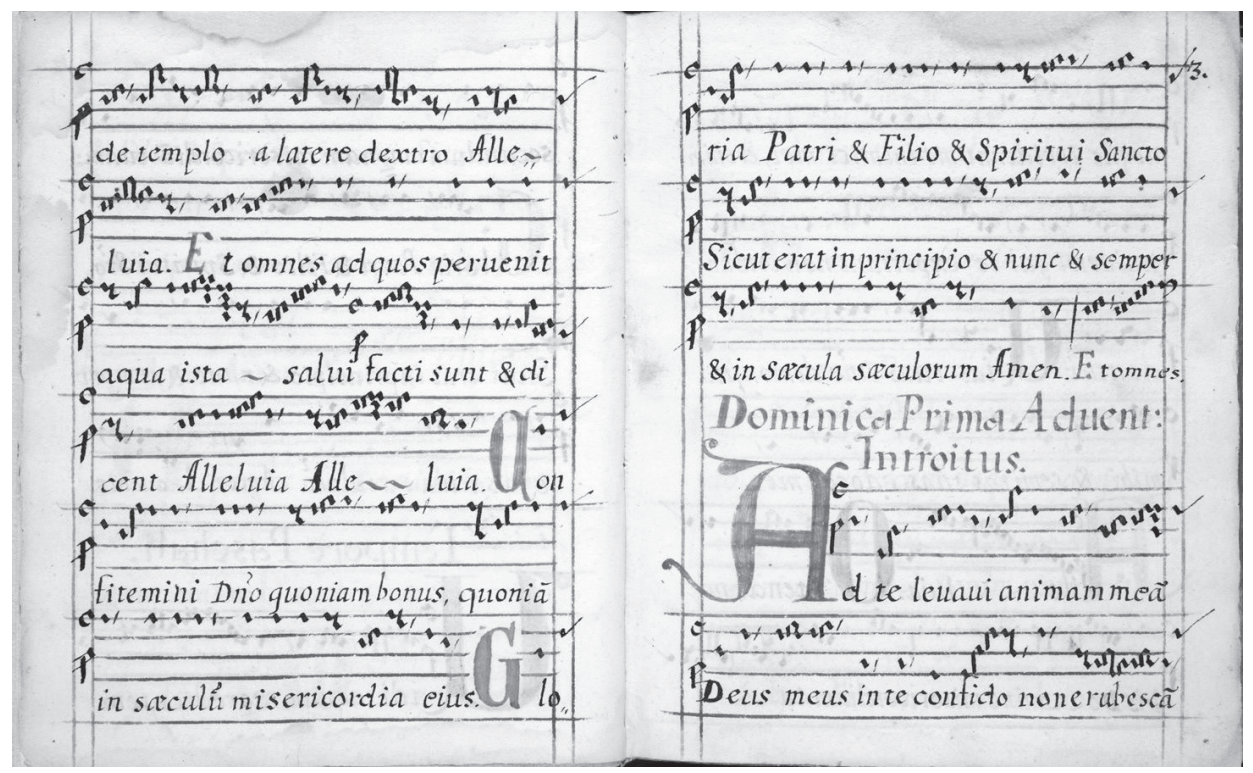

34. See (among others) the studies of Janka Szendrei and Gabriella Gilányi in Note 4.

35. Gabriella Gilányi, “A hiányzó láncszem Egy 1687-es pálos antifonále Crikvenicából” [A missing link? A 1687 Pauline antiphoner from Crikvenica], Magyar Zene 52/1 (February 2014), 5-16.

36. Gabriella Gilányi, "The Processional Oct. Lat. 794 of the Budapest National Széchényi Library. A Re-identification," Studia Musicologica 56/2-3 (2015), 257-289; here: 264-268.

37. H-Bn Ms. Mus. 7240. With a possessor inscription of the Franciscan House in Szombathely. 
FACSIMILE 6 18th-century retrospective plainchant notation: Graduale of the Pápa monastery, from 1748, 300886, The Library of the Theological College of Esztergom, f. 4r

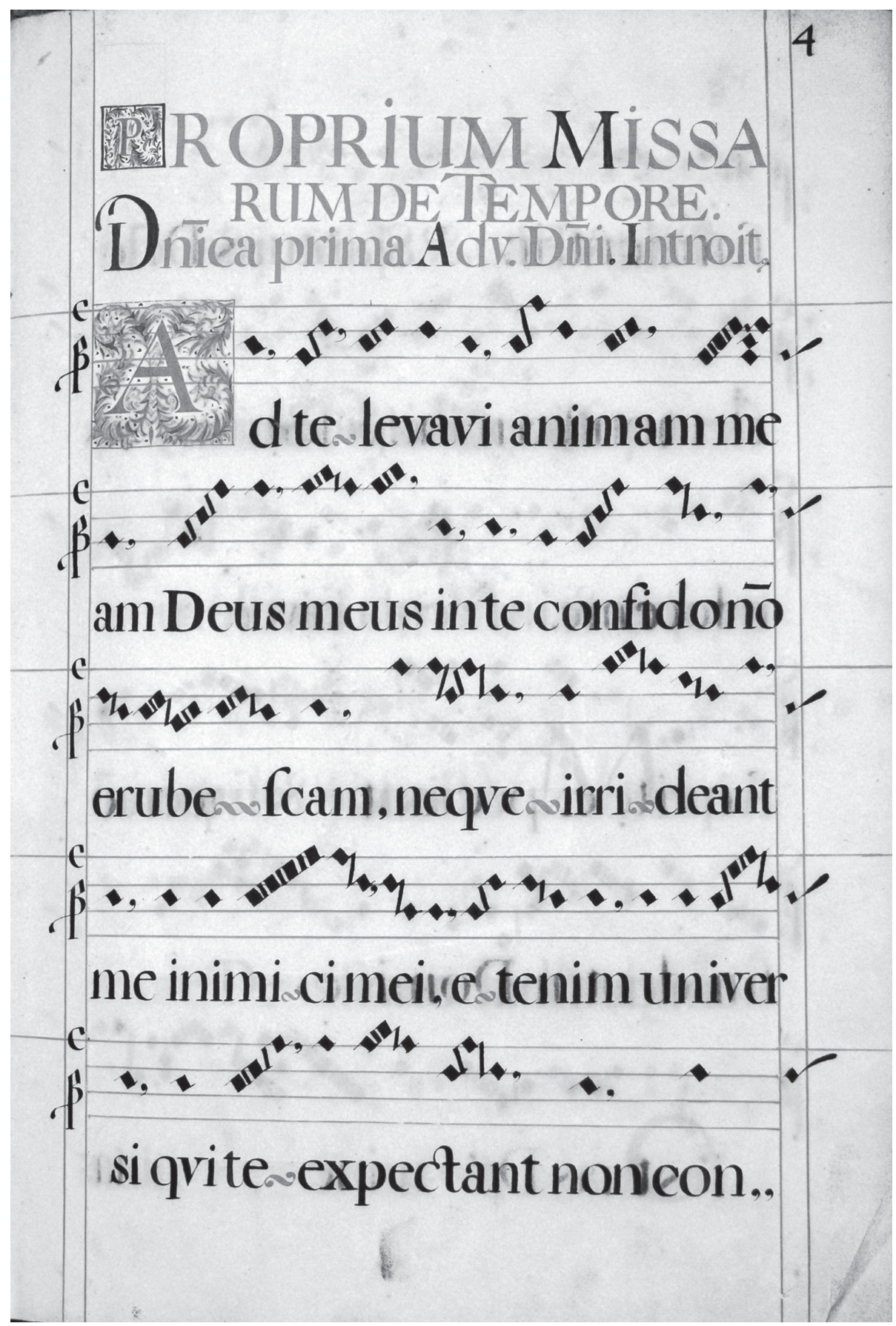


produce a looser picture in the sources (Facsimile 6) ${ }^{38}$ Individual neume forms can be seen in Table 9. Here again the notation presents the Hungarian characteristics: the double pointing of scandicus and downward neumes remains typical of Pauline notation even in the eighteenth century (Facsimile 6). The late handwriting of the Crikvenica Antiphoner marks the final stage. The flexible conjunct-lines of notation still manage to hold the note groups together, but the next stage will certainly be to break them up into notes.

As a new result of examination a distinction can be made between the seventeenth-eighteenth-century Pauline retrospective musical writings. Chant sources from the Croatian province, which was separated from the Hungarian one in 1700, followed a visibly archaic way in chant notation than the post-Tridentine musical manuscripts of the Hungarian province (Table 9). So-called Lepoglava notation, named after the central monastery of the Croatian Paulines end potential place of the scriptorium, which has created an especially square-shaped musical script, is imbued with a kind of modesty alien to the notation in the Hungarian convents. ${ }^{39}$ The Croatian script is less careful and unambiguously cursive as opposed to the Baroque notation of the Pauline Order in the Hungarian province. The Hungarian notation which shows stylized, uniformly shaped rhomboid note heads and homogeneously thin linking lines throughout, appeared in representative paper codices during the eighteenth century as an ornamental notation suitable for establishing a new, restyled form of writing. The appearance of the contemporary Croatian examples as well as their musical scripts are more modest; similarity to Hungarian instances can only be observed in linking the notes to each other.

Pauline notation, over centuries of history, produced a range of distinct and distinguishable creations. The Paulines, unlike Esztergom, developed their own technique for salvaging and stylizing the Hungarian neume structures, but the decisive element in their notation remained a careful, concise, continuous set-out of the sources. Although notation in the Pauline sources proved more faithful to tradition than the Esztergom one, Pauline notation as a whole, throughout its history, can still not be rated as the Hungarian style of notation or as superior to that of Esztergom. The Pauline path can be valued as one of those taken in the history of Hungarian notation: a variant for a special hermitage environment.

38. Gabriella Gilányi, „A latin egyszólamú liturgikus ének Magyarországon a 18. században”, 91-128, here 118-119.

39. Gabriella Gilányi, "The Processional Oct. Lat. 794 of the Budapest National Széchényi Library. A Re-identification”, 265, 267. 
